Article

\title{
Optimization of Key Factors Affecting Methane Production from Acidic Effluent Coming from the Sugarcane Juice Hydrogen Fermentation Process
}

\author{
Alissara Reungsang ${ }^{1,2, *}$, Sakchai Pattra ${ }^{3}$ and Sureewan Sittijunda ${ }^{4}$ \\ 1 Department of Biotechnology, Faculty of Technology, Khon Kaen University, \\ Khon Kaen 40002, Thailand; E-Mail: alissara@kku.ac.th \\ 2 Reserach Group for Development of Microbial Hydrogen Production Process from Biomass, \\ Khon Kaen University, Khon Kaen 40002, Thailand \\ 3 Community Public Health Program, Faculty of Arts and Science, Chaiyaphum Rajabhat University, \\ Chaiyaphum 36000, Thailand; E-Mail: sakpattra@yahoo.com \\ 4 Department of Biotechnology, Faculty of Science, Burapha University, Chonburi 20131, Thailand; \\ E-Mail: joyzeed@gmail.com
}

* Author to whom correspondence should be addressed; E-Mail: alissara@kku.ac.th; Tel./Fax: +66-43-362-121.

Received: 27 August 2012; in revised form: 18 October 2012 / Accepted: 8 November 2012 / Published: 19 November 2012

\begin{abstract}
Response surface methodology with a central composite design was applied to optimize the key factors affecting methane production from the acidic effluent coming from the sugarcane juice hydrogen fermentation process. The parameters studied were substrate concentration, ratio of $\mathrm{NaHCO}_{3}$ to substrate concentration and initial $\mathrm{pH}$. The experimental results showed that substrate concentration and initial $\mathrm{pH}$ had significant individual $(p<0.05)$ effect on methane yield $(M Y)$. However, there was no interactive effect between these variables $\left(p>0.05\right.$ ). The maximum $M Y$ of $367 \mathrm{~mL} \mathrm{CH}_{4} / \mathrm{g}$-volatile solid (VS) added was obtained at the optimum conditions of $13,823 \mathrm{mg}-\mathrm{COD} / \mathrm{L}$, an $\mathrm{NaHCO}_{3}$ to substrate concentration ratio of 3.09 and an initial $\mathrm{pH}$ of 7.07. Under the optimum conditions, $M Y$ was enhanced 4.4-fold in comparison to raw effluent.
\end{abstract}

Keywords: effluent; methane; response surface methodology 


\section{Introduction}

Anaerobic digestion is a biological process known for energy recovery, especially in the form of methane, from wastewater. The recovery of biogas as well as a reduction of chemical oxygen demand (COD) in organic waste and waste stabilization are the main advantages of this process [1]. A two-stage anaerobic digestion process for producing hydrogen and methane from organic materials has been reported [2-7]. In the first stage, acidogenic bacteria convert the organic substances to hydrogen, carbon dioxide and volatile fatty acids (VFAs). Next, acetogenic and methanogenic bacteria convert VFAs into mainly carbon dioxide and methane in the second stage [7].

In our previous study, batch hydrogen fermentation of sugarcane juice by Clostridium butyricum was conducted in which a hydrogen yield of $3.04 \mathrm{~mol} \mathrm{H}_{2} / \mathrm{mol}$ sucrose was obtained [8]. Throughout the successful process of hydrogen production from sugarcane juice, large amounts of organic effluent were generated. The main VFAs in the effluent were butyric and acetic acids, which can cause environmental problems upon disposal due to its high COD value of 18,500 $\mathrm{mg}-\mathrm{COD} / \mathrm{L}$ [8]. VFAs are known as valuable substrates for methane production. Therefore, the possibility of using the effluent from hydrogen fermentation to produce methane by the methanogenic anaerobic sludge was explored in this study.

Environmental factors such as substrate concentration, temperature, $\mathrm{pH}$ and metal ions [1] have great influences on methane production. A high concentration of VFAs has been reported to inhibit methane production from VFAs by mixed anaerobic microorganisms [9]. The optimum $\mathrm{pH}$ range for anaerobic digestion producing methane is 6.8-7.2 [10]. The growth rate of methanogens can be greatly reduced when the $\mathrm{pH}$ value is less than 6.6 [11]. An excessively alkaline $\mathrm{pH}$ can lead to the disintegration of microbial granules and subsequent failure of the digestion process [12]. Therefore, a buffer is needed in the methane production process in order to provide the resistance to significant and rapid $\mathrm{pH}$ changes in the system. Buffer capacity is proportional to the concentration of bicarbonate. $\mathrm{NaHCO}_{3}$ has been widely used to create a buffer system during the anaerobic digestion process [13]. Speece [14] found that an alkalinity to COD concentration ratio (w/w) of 1.2-1.6 was required to sufficiently maintain the $\mathrm{pH}$ at approximately 6.6 during the anaerobic digestion of carbohydrate waste to produce methane. From the aforementioned research, it is obviously seen that in order to achieve a maximum methane production, the key environmental factors should be optimized.

To facilitate the study on the interactive effect of the environmental factors, the statistical experiments could be designed by response surface methodology (RSM). RSM is a statistical model which is helpful for understanding the interactions between the parameters at varying levels and calculating the optimal level of each parameter for a response target [15]. An improvement in product yield, a reduction in process variability, a closer confirmation of the output response and a reduction in the experimental time and overall costs are the outcomes of using this statistical approach $[16,17]$. Previous research have reported the optimization of the process parameters as well as investigated the independent effects of substrate concentration, ratio of $\mathrm{NaHCO}_{3}$ to substrate concentration and the initial $\mathrm{pH}$ on methane production from cellulose and glucose [9], industrial wastewater [10] and municipal solid waste [18]. However, to the best of our knowledge, the interactive effects of these factors on methane production from the acidic effluent coming from hydrogen fermentation process of sugarcane juice have not yet been investigated. 
In the present work, RSM with a central composite design (CCD) was used to optimize the process parameters affecting methane production from the acidic effluent coming from the sugarcane juice hydrogen fermentation process. The individual and interactive effects of the process parameters on methane production were also investigated. The information from this study will not only make use of this waste in a form of renewable energy, i.e., methane but also to reduce the pollutants before it is released to the environment.

\section{Results and Discussion}

\subsection{Statistical Analysis and the Diagnostic Checking of the Fitted Model}

CCD was used to optimize methane yield (MY) from the acidic effluent coming from hydrogen fermentation process of sugarcane juice. The design matrix of the variables in the coded and real value are tabulated in Table 1 with the experimental values of $M Y$ as response.

Table 1. Full factorial $\mathrm{CCD}$ matrix of substrate concentration, ratio of $\mathrm{NaHCO}_{3}$ to substrate and initial $\mathrm{pH}$ of substrate in coded and real values on $M Y$.

\begin{tabular}{ccccccccc}
\hline \multirow{2}{*}{ Run } & $\begin{array}{c}\text { Substrate concentration } \\
(\mathbf{m g - C O D} / \mathbf{L})\end{array}$ & \multicolumn{2}{c}{$\begin{array}{c}\text { NaHCO } \\
\text { r to substrate }\end{array}$} & \multicolumn{2}{c}{ Initial pH } & \multicolumn{2}{c}{ MY } \\
\cline { 2 - 8 } & Code & Actual & Code & Actual & Code & Actual & Observed & Predicted \\
\hline 1 & -1.00 & 10,000 & -1.00 & 2.00 & 1.00 & 8.5 & 270 & 270 \\
2 & 0.00 & 15,000 & 0.00 & 4.00 & 0.00 & 7.0 & 364 & 366 \\
3 & -1.00 & 10,000 & 1.00 & 6.00 & -1.00 & 5.5 & 95 & 97 \\
4 & 0.00 & 15,000 & -1.68 & 0.60 & 0.00 & 7.0 & 294 & 290 \\
5 & 0.00 & 15,000 & 0.00 & 4.00 & 1.68 & 9.5 & 49 & 51 \\
6 & 1.00 & 20,000 & 1.00 & 6.00 & -1.00 & 5.5 & 70 & 74 \\
7 & 0.00 & 15,000 & 1.68 & 7.40 & 0.00 & 7.0 & 262 & 263 \\
8 & -1.00 & 10,000 & -1.00 & 2.00 & -1.00 & 5.5 & 83 & 85 \\
9 & -1.00 & 10,000 & 1.00 & 6.00 & 1.00 & 8.5 & 208 & 204 \\
10 & 1.00 & 20,000 & 1.00 & 6.00 & 1.00 & 8.5 & 79 & 84 \\
11 & 1.00 & 20,000 & -1.00 & 2.00 & -1.00 & 5.5 & 89 & 94 \\
12 & 0.00 & 15,000 & 0.00 & 4.00 & 0.00 & 7.0 & 359 & 368 \\
13 & 0.00 & 15,000 & 0.00 & 4.00 & 0.00 & 7.0 & 372 & 368 \\
14 & 1.00 & 20,000 & -1.00 & 2.00 & 1.00 & 8.5 & 113 & 115 \\
15 & -1.68 & 6,591 & 0.00 & 4.00 & 0.00 & 7.0 & 223 & 232 \\
16 & 0.00 & 15,000 & 0.00 & 4.00 & 0.00 & 7.0 & 362 & 368 \\
17 & 0.00 & 15,000 & 0.00 & 4.00 & 0.00 & 7.0 & 376 & 368 \\
18 & 0.00 & 15,000 & 0.00 & 4.00 & 0.00 & 7.0 & 364 & 368 \\
19 & 1.68 & 23,409 & 0.00 & 4.00 & 0.00 & 7.0 & 246 & 251 \\
20 & 0.00 & 15,000 & 0.00 & 4.00 & -1.68 & 4.5 & 0 & 0 \\
control & - & 18,500 & - & 2.80 & - & 5.5 & 83 & - \\
\hline
\end{tabular}

The predicted values of $M Y$ were obtained from the quadratic model and by evaluating the relationship between substrate concentration $\left(X_{1}\right)$, the ratio of $\mathrm{NaHCO}_{3}$ to substrate $\left(X_{2}\right)$ and the initial 
$\mathrm{pH}\left(X_{3}\right)$. The statistical model was developed by applying multiple regression analysis using the experimental data of $M Y$, which can be given as:

$$
\begin{gathered}
M Y=-3964.4703+0.0944 X_{1}+106.6539 X_{2}+964.7634 X_{3}-0.0014 X_{1} X_{2}-0.0041 X_{1} X_{3} \\
-1.87458 X_{2} X_{3}-0.0000228 X_{1}^{2}-9.0962 X_{2}^{2}-62.0598 X_{3}^{2}
\end{gathered}
$$

The analysis of variance (ANOVA) is necessary to determining the significance and adequacy of the model. The summary of ANOVA results presented in Table 2. The model F-value of 8.77 indicates the model is significant. In addition, the ANOVA of the quadratic regression model demonstrated that the model was highly significant $(p<0.05)$ (Table 2). The linear model terms of substrate concentration $\left(X_{1}\right)$ and the initial $\mathrm{pH}\left(X_{3}\right)$ and the quadratic model terms of the substrate concentration $\left(X_{1}^{2}\right)$ and the initial $\mathrm{pH}\left(X_{3}^{2}\right)$ were significant $(p<0.05)$, indicating that these two variables had an individual effect on $M Y$. However, the linear model terms and quadratic model terms of the ratio of $\mathrm{NaHCO}_{3}$ to substrate $\left(X_{2}\right)$ were insignificant $(p>0.05)$, suggesting that there was no linear effect of this variable on $M Y$. The interactive effects for all of these factors were found to be insignificant $(p>0.05)$ (Table 2). Additionally, the experimental $M Y$ were close to the predicted value using Equation (1) (Figure 1).

Table 2. Analysis of variance for quadratic polynomial model.

\begin{tabular}{cccccccc}
\hline Source & $\begin{array}{c}\text { Sum of } \\
\text { Squares }\end{array}$ & df & $\begin{array}{c}\text { Mean } \\
\text { Square }\end{array}$ & $\begin{array}{c}\text { Coefficient } \\
\text { Estimate }\end{array}$ & $\begin{array}{c}\text { Standard } \\
\text { Error }\end{array}$ & $\begin{array}{c}\text { F } \\
\text { Value }\end{array}$ & $\begin{array}{c}\text { p-value } \\
\text { Prob }>\boldsymbol{F}\end{array}$ \\
\hline Model & 367670.4 & 9 & 40852.27 & 367.729 & 27.837 & 8.7688 & 0.0011 \\
$X_{1}$ & 22466.08 & 1 & 22466.08 & -40.559 & 18.469 & 4.8222 & 0.0528 \\
$X_{2}$ & 17.622 & 1 & 17.622 & -1.135 & 18.469 & 0.0037 & 0.9522 \\
$X_{3}$ & 22709.11 & 1 & 22709.11 & 40.777 & 18.469 & 4.8744 & 0.0518 \\
$X_{1} X_{2}$ & 1580.625 & 1 & 1580.625 & -14.056 & 24.131 & 0.3392 & 0.5731 \\
$X_{1} X_{3}$ & 7501.287 & 1 & 7501.287 & -30.621 & 24.131 & 1.6101 & 0.2332 \\
$X_{2} X_{3}$ & 253.012 & 1 & 253.012 & -5.623 & 24.131 & 0.0543 & 0.8204 \\
$X_{1}^{2}$ & 46799.54 & 1 & 46799.54 & -56.986 & 17.979 & 10.0453 & 0.01 \\
$X_{2}^{2}$ & 19078.23 & 1 & 19078.23 & -36.384 & 17.979 & 4.095 & 0.0706 \\
$X_{3}^{2}$ & 280988.6 & 1 & 280988.6 & -139.634 & 17.979 & 60.3134 & $<0.0001$ \\
$R^{2}=0.8875 ;$ Adequate precision $=9.604$; Coefficient of variation $(\mathrm{CV})=32.71 \%$ & \\
\hline
\end{tabular}

The R-squared of 0.8875 revealed that the model could explain $88.75 \%$ of the variability in the response (Table 2). For a good statistical model, the $R^{2}$ should be in the range of $0.75-1.0$ which indicates a good fit of the model [19]. The relatively high value of $R^{2}$ indicated that the quadratic equation could be used instead of an experimental system under the given conditions. Adequate precision measures the signal to noise ratio. A ratio greater than 4 is desirable. In this study, a ratio of 9.604 was obtained (Table 2) which indicates an adequate signal. Thus, this model can be used to navigate the design space. In addition, the low values of the coefficient of the coefficient of variation (CV) (32.17\%) (Table 2) confirmed a good precision and reliability of this experiment. 
Figure 1. Predicted vs. experimental $M Y$ values.

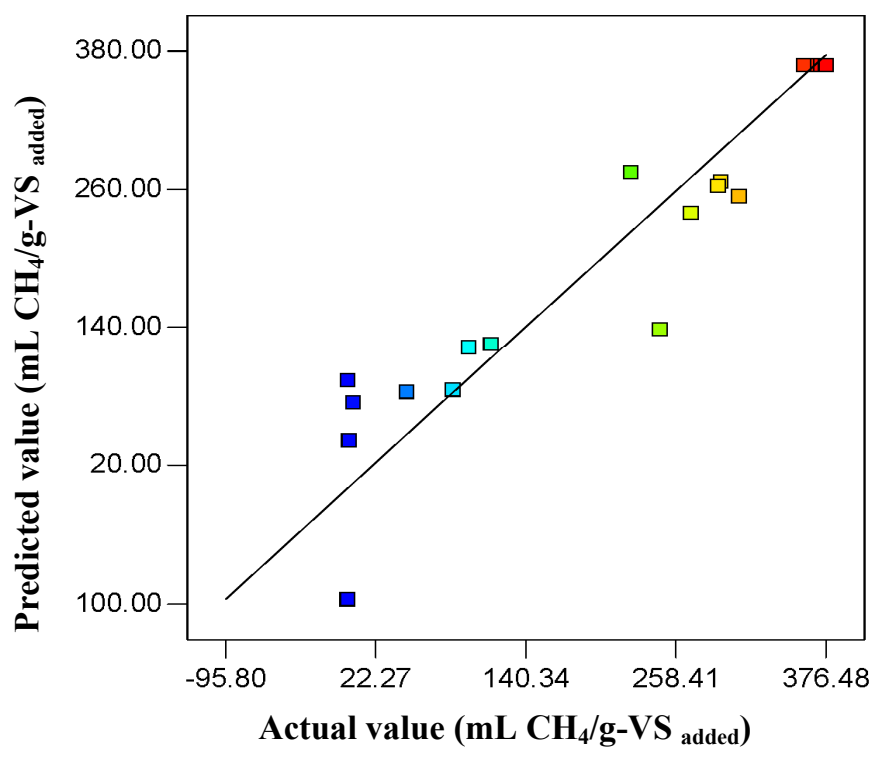

\subsection{Effect of Substrate Concentration, Ratio of $\mathrm{NaHCO}_{3}$ to Substrate and Initial pH on MY from} Acidic Effluent Coming from Hydrogen Fermentation Process of Sugarcane Juice

The interactive effect of substrate concentration, ratio of $\mathrm{NaHCO}_{3}$ to substrate and initial $\mathrm{pH}$ on $M Y$ from acidic effluent coming from hydrogen fermentation process using RSM with CCD was depicted in Figure 2. The $3 \mathrm{D}$ response surface and the $2 \mathrm{D}$ contour plots of substrate concentration and the ratio of $\mathrm{NaHCO}_{3}$ to substrate on $M Y$ are shown in Figure 2(A), (B) with the graphical representations of the regression equation. The predicted maximum value of the substrate concentration and the ratio of $\mathrm{NaHCO}_{3}$ to substrate on $M Y$ are indicated by the top of surface [Figure 2(A)]. The results indicate that the interactive effect of the substrate concentration and the ratio of $\mathrm{NaHCO}_{3}$ to substrate on $M Y$ was not significant $(p>0.05)$ (Table 2).

When the $\mathrm{NaHCO}_{3}$ to substrate concentration ratio and the initial $\mathrm{pH}$ were kept at their central values, it was found that $M Y$ increased with an increase in substrate concentration from 10,000 to $15,000 \mathrm{mg}-\mathrm{COD} / \mathrm{L}$. A further increase in the substrate concentration resulted in a decrease in $M Y$ [Figure 2(A,B)]. The highest $M Y$ of approximately $366 \mathrm{~mL} \mathrm{CH} / \mathrm{g}-\mathrm{VS}_{\text {added }}$ was obtained with an initial substrate concentration of 15,000 $\mathrm{mg}-\mathrm{COD} / \mathrm{L}$ (central value) [Figure 2(A), Table 1].

A decrease in $M Y$ at substrate concentration of $23,409 \mathrm{mg}-\mathrm{COD} / \mathrm{L}$ might be resulted from substrate inhibition (Table 1). An inhibitory effect of high substrate concentration generally occurs in anaerobic digestion processes, depending on the types of substrates and microorganisms. Borja et al. [20] found that $M Y$ as well as volatile solid (VS) reduction decreased remarkably when a substrate concentration i.e., olive mill solid waste, increased from 3 to $15 \mathrm{~g}-\mathrm{VS} / \mathrm{L}$. Murto et al. [21] found that the overloading of sewage sludge and pig manure $(5.9 \mathrm{~g}-\mathrm{VS} / \mathrm{L})$ as a co-substrate in an anaerobic digestion system resulted in microbial inhibition and a significant reduction in $M Y$. 
Figure 2. Response surface plots showed the effects of substrate concentration. (A,B) Ratio of $\mathrm{NaHCO}_{3}$ to substrate concentration and their interactive effect on $M Y$ with the optimum level of initial $\mathrm{pH}$ (7.07); (C,D) The effects of substrate concentration, initial $\mathrm{pH}$ and their interactive effect on $M Y$ with the optimum ratio of $\mathrm{NaHCO}_{3}$ to substrate concentration (3.09); (E,F) The effects of ratio of $\mathrm{NaHCO}_{3}$ to substrate concentration, initial $\mathrm{pH}$ and their interactive effect on $M Y$ with the optimum level of substrate concentration (13,823 mg-COD/L).
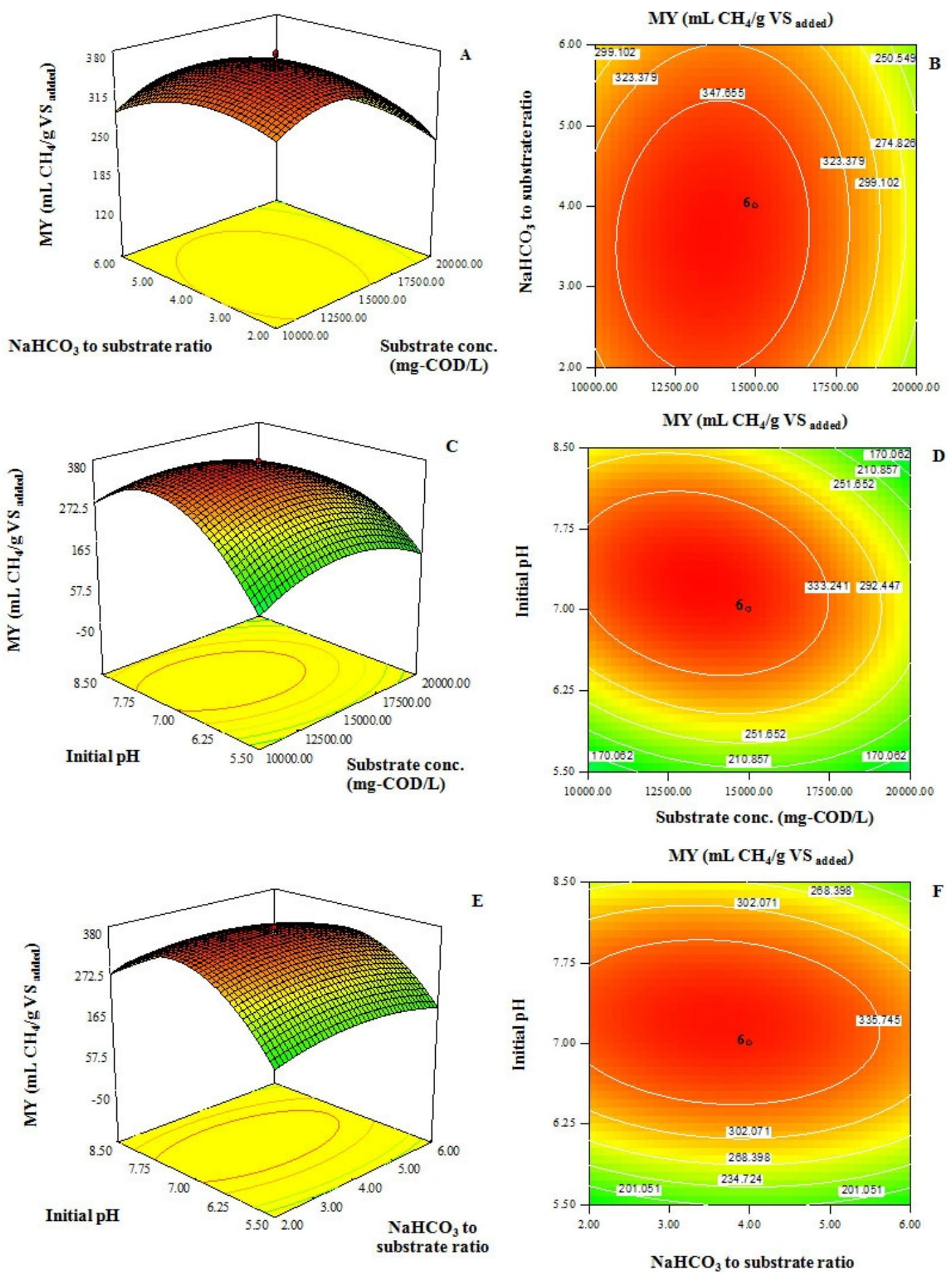

Figure 2(C,E) depicts a graphical relationship between the experimental levels of substrate concentration and the initial $\mathrm{pH}$ on $M Y$. The results indicate that the interactive effect of substrate concentration $\left(X_{1}\right)$ and the initial $\mathrm{pH}\left(X_{2}\right)$ on $M Y$ was not significant $(p>0.05)$ but the initial $\mathrm{pH}$ 
significantly affected the $M Y(p<0.05)$ (Table 2). An increase in the initial $\mathrm{pH}$ from 4.48 to 7.0 led to an increase in $M Y$ [Figure 2(C,E)].

A decrease of $M Y$ could be observed when the initial $\mathrm{pH}$ was increased from 7 to 9.52 . The greatest $M Y$ value of $366 \mathrm{~mL} \mathrm{CH} / \mathrm{g}-\mathrm{VS}_{\text {added }}$ was obtained at an initial $\mathrm{pH}$ of 7.0 when the substrate concentration and the $\mathrm{NaHCO}_{3}$ to substrate ratio were kept at their central values, indicating that the optimum initial $\mathrm{pH}$ for $M Y$ in this study was at 7.0. Methane was not produced at an initial $\mathrm{pH}$ of 4.48 (Run 20, Table 1). Previous research has reported that when the $\mathrm{pH}$ falls below 6.5, methanogenic bacteria are inhibited, resulting in a decrease in $M Y$ efficiency [1], while an excessively alkaline $\mathrm{pH}$ could lead to the disintegration of microbial granules and subsequent failure of the process [12].

The interaction between the $\mathrm{NaHCO}_{3}$ to substrate ratio and the initial $\mathrm{pH}$ on $M Y$ was presented in Figure 2(E,F). The optimum value of the $\mathrm{NaHCO}_{3}$ to substrate ratio and the initial $\mathrm{pH}$ for $M Y$ is indicated on the top of the surface [Figure 2(E)]. The $M Y$ increased with an increase in the ratio of $\mathrm{NaHCO}_{3}$ to substrate, when the substrate concentration and the initial $\mathrm{pH}$ were kept at their central values.

In anaerobic digestion processes, carbon dioxide produced by microorganisms often leads to weak acid condition in aqueous anaerobic systems. Therefore, sufficient bicarbonate alkalinity is required for neutralization [13]. The effect of the alkalinity to substrate ratio is important in the anaerobic digestion process, depending on the type of substrate and microorganism. It was found that the ratio of alkalinity to $\mathrm{COD}$ concentration in a substrate requirement was $1.2-1.6 \mathrm{~g} \mathrm{CaCO}_{3} / \mathrm{g}$ influent $\mathrm{COD}$ which would be sufficient to maintain the $\mathrm{pH}$ above 6.6 in the anaerobic digestion process of carbohydrate waste [14].

The optimum conditions for maximizing the $M Y$ calculated by the obtained model [Equation (1)] were a substrate concentration of $13,823 \mathrm{mg}-\mathrm{COD} / \mathrm{L}$, a ratio of $\mathrm{NaHCO}_{3}$ to substrate of 3.09 and an initial $\mathrm{pH}$ of 7.07. Under the optimum conditions, the predicted maximum $M Y$ of $367 \mathrm{~mL} \mathrm{CH}_{4} / \mathrm{g}-\mathrm{VS}_{\text {added }}$ was obtained from the quadratic regression model. The average maximum observed $M Y$ at the optimum condition was $366 \mathrm{~mL} \mathrm{CH}_{4} / \mathrm{g}-\mathrm{VS}_{\text {added, }}$, which was close to the $\mathrm{RSM}$ experimental result at the center value (Figure 1 and Table 1).

\subsection{Confirmation Experiments and Sufficiency of the Models}

The sufficiency of the predicted response was examined by conducting three additional experiments. The experimental conditions for the substrate concentration, the $\mathrm{NaHCO}_{3}$ to substrate ratio and the initial $\mathrm{pH}$ as well as the experimental results of $M Y$ with the predicted values obtained from the second-order model are shown in Table 3. The predicted value for $M Y$ calculated from the polynomial quadratic Equation 1 for runs 21, 22 and 23 were 269, 331 and $332 \mathrm{~mL} \mathrm{CH} / \mathrm{g}-\mathrm{VS}_{\text {added }}$, respectively. These values were close to the predicted values using CCD. Results confirmed that the RSM with CCD analysis was a useful technique to optimize the $M Y$ from the effluent of hydrogen production process.

The $M Y$ of $366 \mathrm{~mL} \mathrm{CH}_{4} / \mathrm{g}-\mathrm{VS}_{\text {added }}$ achieved in this study was comparable to the $M Y$ obtained from cellulose, boiled rice and fresh garbage of 356, 294 and $277 \mathrm{~mL} \mathrm{CH}_{4} / \mathrm{g}-\mathrm{VS}_{\text {added, }}$, respectively, in a single-phase methane reactor [22]. The optimization could improve a methane production by 4.4 fold in comparison to the raw effluent (Table 1). However, the $M Y$ obtained was lower than that obtained 
from the effluent of the bio-hydrogen production process from food waste which was of $565.76 \mathrm{~mL}$ $\mathrm{CH}_{4} / \mathrm{g}-\mathrm{VS}_{\text {added }}$ [1]. Such a discrepancy might be due to the different in inoculums types and substrate used.

Table 3. Predicted and measured values of the confirmation experiments.

\begin{tabular}{|c|c|c|c|c|c|c|c|c|c|}
\hline \multirow{3}{*}{ Run } & \multicolumn{6}{|c|}{ Variables } & \multirow{2}{*}{\multicolumn{2}{|c|}{$\begin{array}{c}M Y \\
\left.H_{4} / g_{-V S} \text { added }\right)\end{array}$}} & \multirow{3}{*}{$\begin{array}{l}\text { Bias }^{a} \\
(\%)\end{array}$} \\
\hline & \multicolumn{2}{|c|}{$\begin{array}{c}\text { Substrate } \\
\text { concentration } \\
(\mathrm{mg}-\mathrm{COD} / \mathrm{L})\end{array}$} & \multicolumn{2}{|c|}{$\begin{array}{c}\mathrm{NaHCO}_{3} \text { and } \\
\text { substrate ratio }\end{array}$} & \multicolumn{2}{|c|}{ Initial pH } & & & \\
\hline & Code & Actual & Code & Actual & Code & Actual & Predicted & Measured & \\
\hline 21 & 0.00 & 15,000 & 0.00 & 4.00 & 1.00 & 8.5 & 269 & 266 & 0.97 \\
\hline 22 & 0.00 & 15,000 & 1.00 & 6.00 & 0.00 & 7.0 & 331 & 327 & 1.01 \\
\hline 23 & 0.00 & 15,000 & -1.00 & 2.00 & 0.00 & 7.0 & 332 & 331 & 0.33 \\
\hline
\end{tabular}

\subsection{Energy Analysis}

Total energy production from sugarcane juice was calculated based on the hydrogen production and methane yield ( $\mathrm{mL} \mathrm{H}_{2} / \mathrm{L}_{\text {substrate }}$ and $\mathrm{mL} \mathrm{CH}_{4} / \mathrm{kg}-\mathrm{VS}_{\text {substrate, }}$, respectively), relative density of hydrogen and methane $\left(0.089 \mathrm{~kg}-\mathrm{H}_{2} / \mathrm{m}^{3}-\mathrm{H}_{2}\right.$ and $0.72 \mathrm{~kg}-\mathrm{CH}_{4} / \mathrm{m}^{3}-\mathrm{CH}_{4}$, respectively) as well as the heating values of hydrogen and methane $\left(121 \mathrm{MJ} / \mathrm{kg}-\mathrm{H}_{2}, 50 \mathrm{MJ} / \mathrm{kg}-\mathrm{CH}_{4}\right.$, respectively) [23]. From our previous experiment, sugarcane juice was used to produce hydrogen and the highest hydrogen yield (HY) of 2.29 $\mathrm{L} \mathrm{H}_{2} / \mathrm{L}_{\text {substrate }}$ was obtained under the optimum replacement ratio of $50 \%(\mathrm{v} / \mathrm{v})$ [8], Therefore, the energy production from hydrogen was $[2.29 \times(0.089 \times 121)]=24.66 \mathrm{~kJ}$. In this study, the acidic effluent coming from hydrogen fermentation process of sugarcane juice was used to produce methane and the maximum $M Y$ of $331 \mathrm{~mL} \mathrm{CH}_{4} / \mathrm{g}-\mathrm{VS}_{\text {added }}$ was obtained under the optimum conditions. Thus, the energy production from methane was $[(331 \times(0.72 \times 50)]=11.92$ MJ. Hence, the net energy generated from this sequential process (hydrogen production in the first phase and methane production in the second phase) was 11.94 MJ. The results suggested that the acidic effluent coming from hydrogen fermentation process of sugarcane juice is worth to be used for methane production. In addition, a sequential fermentation process would give a higher energy production than a production of hydrogen or methane alone.

\section{Experimental Section}

\subsection{Methanogenic Anaerobic Seed Sludge}

Methanogenic anaerobic seed sludge was taken from the municipal anaerobic wastewater treatment plant in Ube (Yamaguchi, Japan). Total solid (TS), suspended solids (SS) and volatile suspended solid (VSS) of methanogenic seed sludge were (all in $\mathrm{mg} / \mathrm{L}$ ) $12,000 \pm 35,10,000 \pm 51$, and 7,300 \pm 100 , respectively. The methanogenic bacteria in the seed sludge were acclimatized by incubating the seed sludge in $10 \mathrm{~g} / \mathrm{L}$ glucose under anaerobic conditions at $30^{\circ} \mathrm{C}$ for 30 days prior the usage. 


\subsection{Substrate}

The effluent from hydrogen fermentation of sugarcane juice by $C$. butyricum with a HY of $3.04 \mathrm{~mol} \mathrm{H}_{2} / \mathrm{mol}$ sucrose [8] was used as the substrate. The main VFAs in this effluent were butyric and acetic acids with a high COD value of $18,500 \mathrm{mg}-\mathrm{COD} / \mathrm{L}$. The $\mathrm{pH}$ of the effluent from hydrogen fermentation was 5.5. The effluent was kept at $4{ }^{\circ} \mathrm{C}$ before used in this experiment. The physical and chemical characteristics of the effluent are presented in Table 4.

Table 4. Characteristics of the acidic effluent coming from hydrogen fermentation process of sugarcane juice.

\begin{tabular}{cc}
\hline Chracteristics & Concentration \\
\hline Chemical oxygen demand $(\mathrm{mg}-\mathrm{COD} / \mathrm{L})$ & $18,500 \pm 12$ \\
Total organic carbon $(\mathrm{TOC}, \mathrm{mg} / \mathrm{L})$ & $7,600 \pm 10$ \\
Total nitrogen $(\mathrm{TN}, \mathrm{mg} / \mathrm{L})$ & $252 \pm 30$ \\
Total phosphorus $(\mathrm{TP}, \mathrm{mg} / \mathrm{L})$ & $73 \pm 6$ \\
Acetic acid $(\mathrm{HAc}, \mathrm{mg}-\mathrm{COD} / \mathrm{L})$ & $3,390 \pm 54$ \\
Butyric acid $(\mathrm{HBu}, \mathrm{mg}-\mathrm{COD} / \mathrm{L})$ & $13,000 \pm 13$ \\
Propionic acid $(\mathrm{HPr}, \mathrm{mg}-\mathrm{COD} / \mathrm{L})$ & $260 \pm 20$ \\
Chloride $(\mathrm{Cl})(\mathrm{mg} / \mathrm{L})$ & $1,586 \pm 56$ \\
Volatile solids $(\mathrm{VS}, \mathrm{mg} / \mathrm{L})$ & $5,870 \pm 26$ \\
\hline
\end{tabular}

\subsection{Experimental Design}

The effects of three key environmental factors including substrate concentration, the ratio of $\mathrm{NaHCO}_{3}$ to substrate concentration and the initial $\mathrm{pH}$ on $M Y$ were investigated using CCD. The levels of the factors used for $M Y$ optimization are presented in Table 5. Twenty runs of the experiment were required for this procedure, as given in Table 1. Control is the acidic effluent coming from hydrogen fermentation of sugarcane juice without any adjustments. The independent variables were coded for statistical calculations according to the following equation:

$$
x_{i}=X_{I}-X_{0} / \Delta X
$$

where $X_{I}$ is the independent variable coded value, $X_{I}$ is the real value of the independent variable, $X_{0}$ is the real value of the independent variable at the center point and $\Delta X$ is the step change. The response variable, $M Y$, was fitted to a polynomial quadratic model in order to correlate the response variable to the independent variables. The general form of the predictive polynomial quadratic equation is as follows:

$$
Y=\beta_{0}+\sum \beta_{i} X_{i}+\sum \beta_{i i} X_{i}^{2}+\sum \beta_{i i} X_{i j}
$$

where $Y$ is the predicted response $(M Y), \beta_{0}$ is the offset term, $\beta_{i}$ is the linear coefficient, $\beta_{i i}$ is the squared coefficient, $\beta_{i j}$ is the interaction coefficient, and $X_{i}$ is the input variables. The response variable $(M Y)$ was fitted using a predictive polynomial quadratic equation [Equation (3)] in order to correlate the response variable to the independent variables [24]. The statistical software Design-Expert (Demo version 7.0, Stat-Ease, Inc., Minneapolis, MN, USA) was used for regression and graphical analysis of the experimental data. Three-dimensional (3D) response surfaces and two-dimensional (2D) contour plots were built to give visual insight into the effects of these factors on $M Y$. 


\subsection{Batch Fermentation}

Batch fermentation for methane production was conducted in $100 \mathrm{~mL}$ serum bottles with a working volume of $50 \mathrm{~mL}$. The fermentation media contained the following constituents dissolved in distilled water: inoculum $(10 \% \mathrm{v} / \mathrm{v})$, and different concentrations of the components that needed to be optimized i.e., substrate concentration, the ratio of $\mathrm{NaHCO}_{3}$ to substrate concentration (Table 1). The initial $\mathrm{pH}$ of fermentation media was adjusted using $5 \mathrm{~N} \mathrm{NaOH}$ or $3 \mathrm{~N} \mathrm{HCl}$ according to the experimental design (Table 1).

Table 5. Experimental range and levels of the independent variables.

\begin{tabular}{lccccc}
\hline \multirow{2}{*}{ Variables } & \multicolumn{5}{c}{ Range and levels } \\
\cline { 2 - 6 } & $-\boldsymbol{\alpha}(\mathbf{- 1 . 6 8 2})$ & Low (-1) & Central (0) & High (1) & $+\boldsymbol{\alpha}(\mathbf{1 . 6 8 2})$ \\
\hline$X_{1}=$ Substrate concentration $(\mathrm{mg}-\mathrm{COD} / \mathrm{L})$ & 6,591 & 10,000 & 15,000 & 20,000 & 23,409 \\
$X_{2}=$ Ratio of $\mathrm{NaHCO}_{3}$ to substrate concentration & 0.64 & 2.00 & 4.00 & 6.00 & 7.36 \\
$X_{3}=$ Initial $\mathrm{pH}$ of substrate & 4.48 & 5.50 & 7.00 & 8.50 & 9.52 \\
\hline
\end{tabular}

All serum bottles were tightly sealed with rubber septa and aluminum cap after the seed inoculum and substrate were added. The headspace of the bottles was purged with argon gas for 5 min to ensure anaerobic conditions. The serum bottles were incubated at $30^{\circ} \mathrm{C}$ on a horizontal shaker at $150 \mathrm{rpm}$. All treatments were carried out in triplicates.

\subsection{Analytic Methods}

Concentrations of TS, SS, VS, VSS, COD, total nitrogen (TN), total phosphorus (TP) and $\mathrm{Cl}^{-}$were measured according to standard methods [25]. Total organic carbon (TOC) was measured using a TOC analyzer (Shimadzu TOC-5000). For VFAs analysis, $3 \mathrm{~mL}$ of fermentation broth was first centrifuged at $12,000 \mathrm{rpm}$ for $5 \mathrm{~min}$ to obtain clarified supernatants which were then acid fixed by mixing with $0.1 \mathrm{~N} \mathrm{HCl}$ (ratio $1: 1 \mathrm{v} / \mathrm{v}$ ) and filtered through a $0.45 \mu \mathrm{m}$ nylon membrane. The concentrations of VFAs in the filtrate were determined by gas chromatography (GC, Model 8APF, Shimadzu, Japan) equipped with a flame ionization detector (FID) and a $3 \mathrm{~m} \times 3.2 \mathrm{~mm}$ glass column packed with 30/60 Unisol F-200 mesh. The operation conditions were set according to Hasyim et al. [26]. The volume of biogas was measured daily by the plunger displacement method using appropriately sized wetted glass syringes [27]. The components of biogas in the headspace, including hydrogen, nitrogen, methane and carbon dioxide, were determined by GC (Model GC-8APT, Shimadzu, Japan) equipped with a thermal conductivity detector (TCD). The operation conditions were set according to Hasyim et al. [26].

\section{Conclusions}

Only the substrate concentration and the initial $\mathrm{pH}$ had significant individual effects on $M Y$. The interactive effects for all of these factors were found to be insignificant $(p>0.05)$. The optimum conditions for maximizing $M Y$ were a substrate concentration of $13,823 \mathrm{mg}-\mathrm{COD} / \mathrm{L}, \mathrm{a} \mathrm{NaHCO}_{3}$ to substrate ratio of 3.09 and an initial $\mathrm{pH}$ of 7.07 in which a maximum $M Y$ of $367 \mathrm{~mL} \mathrm{CH} 4 / \mathrm{gVS}_{\text {added }}$ was obtained. Under the optimum conditions the $M Y$ was 4.4-fold greater than the raw effluent (control). The model validation experiment confirmed that the $M Y$ from the experimental data was close to the 
predicted data suggesting the adequacy of the model. Net energy generated from the sequential process (hydrogen production in the first phase and methane production in the second phase) was $11.94 \mathrm{MJ}$, which suggested that the acidic effluent coming from the sugarcane juice hydrogen fermentation is worthy of use for methane production.

\section{Acknowledgments}

This research was supported by Fermentation Research Center for Value-Added Agricultural Products, Khon Kaen University, and the National Research University Project through the Biofuels Research Cluster-Khon Kaen University, Office of the Higher Education Commission.

\section{References}

1. Wang, X.; Nui, D.J.; Yang, X.S.; Zhao, Y.C. Optimization of methane fermentation from effluent of bio-hydrogen fermentation process using response surface methodology. Bioresour. Technol. 2008, 99, 4292-4299.

2. Cooney, M.; Maynaed, N.; Cannizzaro, C.; Benemann, J. Two-phase anaerobic digestion for production of hydrogen-methane mixtures. Bioresour. Technol. 2007, 98, 2641-2651.

3. Liu, D.; Liu, D.; Zeng, R.J.; Angelidaki, I. Hydrogen and methane production from household solid waste in two-stage fermentation process. Water Res. 2006, 40, 2230-2236.

4. Ting, C.H.; Lee, D.J. Production of hydrogen and methane from wastewater sludge using anaerobic fermentation. Int. J. Hydrog. Energy 2007, 32, 677-682.

5. Ueno, Y.; Tatara, M.; Fukui, H.; Makiuchi, T.; Goto, M.; Sode, K. Production of hydrogen and methane from organic solid wastes by phase-separation of anaerobic process. Bioresour. Technol. 2007, 98, 1861-1865.

6. Xie, B.; Cheng, J.; Zhou, J.; Song, W.; Liu, J.; Cen, K. Production of hydrogen and methane from potatoes by two-phase anaerobic fermentation. Bioresour. Technol. 2008, 99, 5942-5946.

7. Zhu, H.; Stadnyk, A.; Beland, M.; Seto, P. Co-production of hydrogen and methane from potato waste using a two-stage anaerobic digestion process. Bioresour. Technol. 2008, 99, 5078-5084.

8. Plangklang, P.; Reungsang, R.; Pattra, S. Enhanced bio-hydrogen production from sugarcane juice by immobilized Clostridium butyricum on sugarcane bagasse. Int. J. Hydrog. Energy 2012, 37, $15525-15532$.

9. Siegert, I.; Banks, C. The effect of volatile fatty acid additions on the anaerobic digestion of cellulose and glucose in batch reactors. Process Biochem. 2005, 40, 3412-3418.

10. Ward, A.J.; Hobbs, P.J.; Holliman, P.J.; Jones, D.L. Optimization of the anaerobic digestion of agricultural resources. Bioresour. Technol. 2008, 99, 7928-7940.

11. Mosey, F.E.; Fernandes, X.A. Patterns of hydrogen in biogas from the anaerobic digestion of milk-sugars. Water Sci. Technol. 1989, 21, 187-196.

12. Sandberg, M.; Ahring, B.K. Anaerobic treatment of fish-meal process wastewater in a UASB reactor at high pH. Appl. Microbiol. Biotechnol. 1992, 36, 800-804.

13. Guwy, A.J.; Hawkes, F.R.; Wilcoxs, S.J.; Hawker, D.L. Neural network and on-off control of bicarbonate alkalinity in a fluidized-bed anaerobic digester. Water Res. 1997, 31, 2019-2025. 
14. Speece, R.E. Anaerobic Biotechnology for Industrial Wastewater, 1st ed.; Archae Press: Nashville, TN, USA, 1996.

15. Reddy, P.R.M.; Ramesh, B.; Mrudula, S.; Reddy, G.; Seenayya, G. Production of thermostable $\beta$-amylase by Clostridium thermosulfurogenes SV2 in solid-state fermentation: optimization of nutrient levels using response surface methodology. Process Biochem. 2003, 39, 267-277.

16. Elibol, M. Optimization of medium composition for actinorhodin production by Streptomyces coelicolor A3(2) with response surface methodology. Process Biochem. 2004, 39, 1057-1062.

17. Xiong, C.; Jinhua, W.; Dongsheng, L. Optimization of solid-state medium for the production of inulinase by Kluyveromyces sp. S120 using response surface methodology. Biochem. Eng. J. 2007, 34, 179-184.

18. Liu, C.F.; Yuan, X.Z.; Zeng, G.M.; Li, W.W.; Li, J. Prediction of methane yield at optimum pH for anaerobic digestion of organic fraction of municipal solid waste. Bioresour. Technol. 2008, 99, 882-888.

19. Niladevi, K.N.; Sukumaran, R.K.; Jacob, N.; Anisha, G.S.; Prema, P. Optimization of laccase production from a novel strain Streptomyces psammoticus using response surface methodology. Microbiol. Res. 2009, 164, 105-113.

20. Borja, R.; Rincon, B.; Raposo, F.; Alba, J.; Martin, A. A study of anaerobic digestibility of two-phases olive mill solid waste (OMSW) at mesophilic temperature. Process Biochem. 2002, 38, 733-742.

21. Murto, M.; Bjornsson, L.; Mattiasson, B. Impact of food industrial waste on anaerobic co-digestion of sewage sludge and pig manure. J. Environ. Manag. 2004, 70, 101-107.

22. Cho, J.K.; Park, S.C.; Chang, H.N. Biochemical methane potential and solid state anaerobic digestion of Korean food wastes. Bioresour. Technol. 1995, 52, 245-253.

23. Chandra, R.; Takeuchi, H.; Hasegawa, T. Methane production from lignocellulosic agricultural crop wastes: A review in context to second generation of biofuel production. Renew. Sustain. Energy Rev. 2012, 16, 1462-1476.

24. Cuetos, M.J.; Gomez, X.; Escapa, A.; Moran, A. Evaluation and simultaneous optimization of bio-hydrogen production using $3^{2}$ factorial design and the desirability function. J. Power Source 2007, 169, 131-139.

25. Standard Methods for the Examination of Water and Wastewater, 17th ed.; American Public Health Association: Washington, DC, USA, 1989.

26. Hasyim, R.; Imai, T.; O-Thong, S.; Sulistyowati, L. Biohydrogen production from sago starch in wastewater using an enriched thermophilic mixed culture from hot spring. Int. J. Hydrog. Energy 2011, 36, 14162-14171.

27. Owen, W.; Stuckey, C.; Healy, J.; Young, L.; McCarty, P. Bioassay for monitoring biochemical methane potential and anaerobic toxicity. Water Res. 1978, 13, 485-493.

(C) 2012 by the authors; licensee MDPI, Basel, Switzerland. This article is an open access article distributed under the terms and conditions of the Creative Commons Attribution license (http://creativecommons.org/licenses/by/3.0/). 